\title{
Diamicton facies in the vicinity of Duhlata cave, Bosnek karst region, Southwestern Bulgaria
}

\section{Диамиктонов фациес в околностите на пещерата Духлата, Боснекски карстов район, Югозападна България}

\author{
Athanas Chatalov, Dilyana Hristova \\ Атанас Чаталов, Диляна Христова
} Sofia University “St. Kliment Ohridski”, 15 Tsar Osvoboditel Blvd., 1504 Sofia; E-mails: chatalov@gea.uni-sofia.bg;
martinovah@uni-sofia.bg

\begin{abstract}
Karst caverns in the Upper Triassic dolostones of the Rusinovdel Formation are filled with allochthonous clastics (brecciaconglomerates with maximum boulder size) and locally with speleothems (flowstones). Deposition of the former (diamicton facies) by debris flows resulted from extreme flood events along the upper reaches of Struma river. The polymict material reflects erosion of various rock types in the source area but is dominated by resedimented Lower Triassic red beds. The diamictons are more or less similar to the few known examples from Quaternary karst caves.
\end{abstract}

Keywords: diamicton facies, karst, Duhlata cave, Southwestern Bulgaria.

Боснекският карстов район има площ около $30 \mathrm{~km}^{2}$ и обхваща югозападната част на Витоша плюс малка част от източните склонове на планината Голо бърдо (Angelova et al., 2005). Карстьт в него се дефинира като повърхностен и подповърхностен, и включва над 30 пещери. Карстообразуването е протекло през три етапа: плейстоценски, холоценски и съвременен. Неговата еволюция е контролирана главно от тектонски процеси и развитието на р. Струма (Shanov, Kostov, 2015). Духлата е най-голямата пещера не само в Боснекския карстов район, но и в цяла България. Тя представлява сложен лабиринт с дендровидна структура, разширяващ се ветрилообразно към р. Струма. Произходът на пещерата се свързва пряко с дейността на речни води (Angelova et al., 2005).

Извършените теренни изследвания в близост до главния вход на Духлата показаха наличието на карстови каверни, запълнени със седиментен материал. Каверните са образувани в горнотриаски доломити на Русиновделската свита, които се разкриват край шосето между селата Боснек и Чуйпетлово. Първите каверни се проследяват на около 12 m от основата на свитата, като дости- гат стратиграфски приблизително до средата на нейния разрез. В тяхното разположение, големина, морфология и пълнеж се установяват някои закономерности. Така напр., гъстотата и размерите им нарастват около входа на пещерата, което показва, че те са били част от пещерната система. В този участьк се наблюдава най-голямата каверна с дължина 10 m и ширина от 2,5 до $4 \mathrm{~m}$. С отдалечаване от него, размерите на каверните намаляват до дециметров обхват. В морфоложко отношение могат да се обособят два главни типа. Най-разпространена е неправилната, а по-рядко се среща удължената форма, като във втория случай каверните са разположени предимно субвертикално спрямо земната повърхност. Повечето карстови каверни са запълнени с кластичен материал и карбонатни спелеотеми, които в много случаи се редуват. Количественото съотношение между двата типа пълнеж варира в широки граници, но навсякъде доминира кластичният компонент. Каверни, които са запълнени само със спелеотеми, се наблюдават в средните нива на Русиновделската свита.

Кластичните седименти са изградени от псефитни късове (гравий до валуни) и псамитен 
матрикс. По-големите каверни съдържат по-едри класти, чийто размер нараства от стените към централната част. В морфоложко отношение късовете са предимно полуръбести и полузаоблени, което дефинира запълващия материал като брекчоконгломерат. Степента на сферичност е променлива и най-общо намалява обратнопропорционално на късовия размер. Преобладават фрагменти с неправилни очертания, но се наблюдават и такива с плочеста, субсферична и елипсовидна форма. Типични характеристики на брекчоконгломератите са класт-поддържана структура и много слаба сортировка на псефитния компонент (фиг. 1a). В някои участъци от кластичния пълнеж (с максимален късов размер до дребен чакъл) степента на сортировка е умерена. По отношение на петрографския състав водещо място заемат фрагментите от розовочервени пясъчници и гравийни брекчоконгломерати (фиг. 1б). По-слабо са застъпени късовете от кварц, гранитоиди, други плутонични скали (сиенити, монцонити, габро, диорити) и андезитобазалтови вулканити. Още по-редки са кластите от доломити, варовици, аргилити, алевролити и сиви пясьчници. Това петрографско разнообразие определя полимиктовия характер на брекчоконгломератите. Кластичният пълнеж се отличава повсеместно с масивна текстура, но в някои каверни е налице слабоизразена обратна градация по отношение на късовия размер. Псамитният матрикс показва светлоохрест до кафеникав цвят и също се характеризира със слаба сортировка на зърната (от едър алеврит до грубозърнест псамит). В отделни участъци на някои каверни количественото съотношение между късовете и матрикса се променя, като класт-поддьржаната структура локално прехожда в матрикс-поддържана структура.

По своите макроскопски характеристики спелеотемите се дефинират като флоустоуни (flowstones), т.е. притежават ламиниран строеж, обусловен от редуването на ламини с раз- лично оцветяване и дебелина. Спелеотемите изграждат самостоятелни слоеве в каверните и/ или оформят обвивки около псефитните късове на брекчоконгломератите (фиг. 1в). В първия случай флоустоуните облицоват предимно стени, сводове или основата на каверните, достигайки дебелина няколко сантиметра, а когато са разположени сред кластичния материал, дебелината на слоевете рядко надхвърля $1 \mathrm{~cm}$. Обвивките около псефитни късове са дебели до няколко милиметра, като в някои от тях могат да се наблюдават ясно отделни генерации флоустоуни. На места псефитните класти видимо „Плуват” сред спелеотеми, без да се намират в контакт с матрикса или други късове. Сравнително рядко, сред кластичния материал се установяват и преотложени ръбести фрагменти от флоустоуни.

Седиментният пълнеж на карстови празнини може да включва кластичен, химично отложен и органичен материал. Пьрвият тип, който има най-голям относителен дял в природата, се поделя съответно на алохтонен и автохтонен по произход. Алохтонната кластика обхваща скални късове и зърна, привнесени в карстовата система чрез флувиална дейност и/или епизодични гравитационни потоци, докато автохтонният материал е продукт на физични процеси, протичащи в самата окарстена скала. Алохтонният пьлнеж, който по зърнов размер може да варира от пелитни частици до валунни късове, обикновено съдържа различно количество примесена автохтонна кластика.

Разпознаването на различни фациеси сред пещерните кластични седименти може да бъде направено на базата на комбинираното описание на зърновия размер и сортировката на материала. Такава опростена схема е предложена от Bosch \& White (2004), като в нея се обособяват пет фациеса, образувани чрез различен транспортиращ механизъм: канален, талвегов, остатъчен, диамиктонов и фациес на застояла
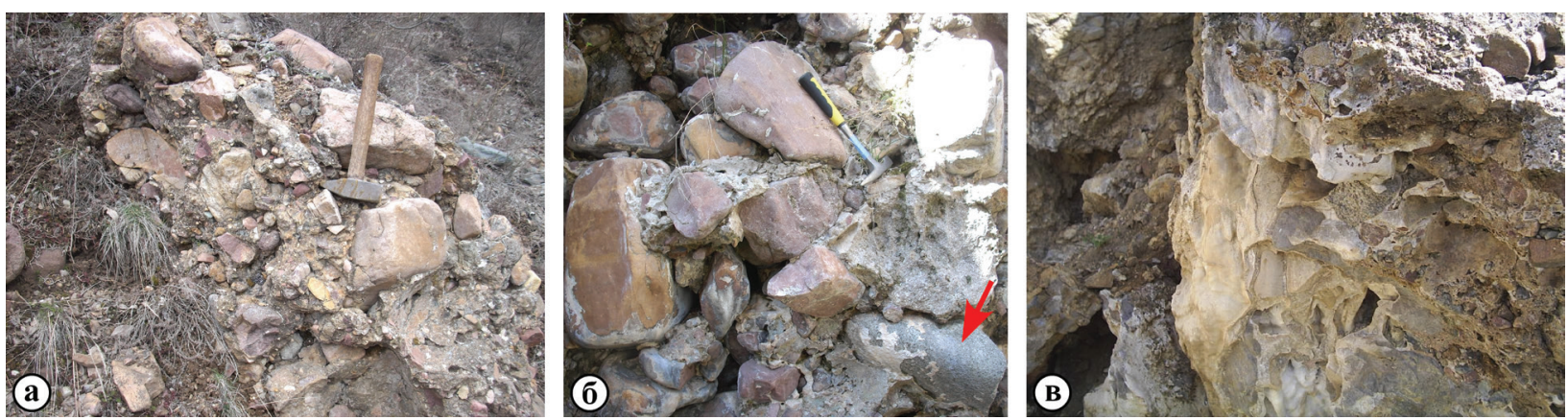

Фиг. 1. $a$ - диамиктонов фациес, съдържащ слабосортирани псефитни късове и псамитен матрикс; $\sigma$ - валуни от розовочервени пясъчници в централната част на голяма каверна, със стрелка е обозначен гранитоиден къс; $в-$ белезникави флоустоуни, изграждащи самостоятелни слойчета и обвивки около псефитни класти 
вода. По липсата на стратификация и своите структурни характеристики (много слаба сортировка, максимален валунен размер и хаотично разположение на псефитните късове) пълнежът на каверните следва да се отнесе към четвъртия фациес. Диамиктоновите отложения се интепретират главно като продукт на високоенергийни дебритни потоци, в които цялата седиментна маса се придвижва под формата на механична суспензия по протежение на карстови канали и каверни посредством турбулентността на самия дебритен поток. Диамиктоновият фациес е найтипичен за карстови терени в дренажни области с висок хипсометричен градиент, както и за карстови каверни в близост до входове на пещери (Bosch, White, 2004). Самите дебритни потоци възникват най-често от бурни наводнения, но също така в резултат на земни свличания или срутване на понори. По-рядко образуването на диамиктони може да бъде свързано с процеси на замръзване/топене и последвали масови движения на материал в периглациални обстановки. Според Herman et al. (2012), хипсометричният градиент между водосборната площ и карстовия терен контролира скоростта на дебритния поток, а по този начин и максималния зърнов размер на транспортирания материал. Същите автори посочват два основни фактора за конкретните условия на седиментен транспорт през карстовата система: а) размерьт на каверните и каналите трябва да бъде достатъчно голям, за да осигури преминаването на късове с определен размер; б) скоростта на самия поток трябва да бъде достатъчно висока, за да стане възможно придвижването на такива късове. Актуалистични наблюдения показват, че дебритните потоци отлагат носения от тях материал сравнително бързо, когато скоростта им спадне под критичния праг на седиментен транспорт за даден зърнов размер (напр., вследствие от разширяване на карстовите празнини). Локалната поява на обратна градация при псефитните късове се интерпретира с отлагане от един импулс на кластичен привнос при постепенно увеличаване на скоростта на транспортиращия поток, докато преходът от класт-поддържана към матриксподдържана структура отразява спадане на потоковата скорост.

Съставът на алохтонния кластичен материал в пещери зависи пряко от петрографския състав на скалите в подхранващата област, която по правило се намира в близост до карстовата система (Bosch, White, 2004). Псефитните късове в описаните диамиктони отразяват наличието на определени скални типове, разкриващи се около горното течение на р. Струма. Така напр., преобладаващите фрагменти от розовочерве- ни пясъчници и гравийни брекчоконгломерати произхождат от непосредствено разположените долнотриаски седименти на Мърводолската свита, като подобни скали участват и в състава на горнокарбонско-пермските Габренска свита и Равулянска свита, разкриващи се в съседство с долнотриаските кластити. Други източници на псефитен материал в подхранващата област, чиито късове се разпознават в пълнежа на каверните, включват горнокредни скали на Витошкия плутон и Витошкия вулкански комплекс, които изграждат най-горните участъци по течението на р. Струма. Сред останалите възможни продукти на ерозия и преотлагане попадат долно-среднотриаски, юрски и горнокредни силицикластични и карбонатни седименти, както и скали на горнокредния Плански плутон. Част от доломитните псефитни късове, които притежават неправилна форма и ниска степен на заобленост, най-вероятно има автохтонен произход. Освен кластични зърна, транспортирани чрез дебритните потоци, матриксът на диамиктоните може да съдържа неразтворим остатък от излужване на самите окарстени доломити, както и инфилтриран почвен материал, придвижен низходящо от метеорни води или по чисто гравитационен път.

Наличието на флоустоуни и диамиктони в някои каверни свидетелства за редуване на химично утаяване и механична седиментация. Добре известно е, че спелеотеми се отлагат от съдържащи $\mathrm{CaCO}_{3}$ разтвори, които се просмукват главно от земната повърхност във вадозната зона на карстовата система. Това причинява съответно дегазиране на разтворите и тяхното пренасищане спрямо $\mathrm{CaCO}_{3}$, водещо до утаяване на калцит или арагонит. Друг механизъм, застъпен по-ограничено в природата, е свързан с изпарение на споменатите разтвори в пещери, имащи добра вентилация, сезонно пресъхващи пещери или около пещерни входове. В конкретния случай флоустоуните са били образувани от тънък слой вода, течаща бавно и продължително по сводовете, стените или основата на каверните, както и върху механично отложения субстрат, т.е. кластичните късове. Ламинацията в тях отразява промени от различен мащаб във вадозната зона, които са контролирани главно от климатични и сезонни колебания (температура, влажност, ниво на грунтовите води). Образуването на флоустоуни е било прекъсвано през периоди с отлагане на алохтонна кластика, както и евентуално през периоди с преобладаващо разтваряне или осушаване на карстовата система. Наблюдаваните редки фрагменти от спелеотеми представляват продукт на ерозия, свързана с протичането на 
високоенергийно събитие, т.е., навлизането на дебритен поток в част от пещерата. Подновеното утаяване на флоустони е способствало за съхранение на по-рано отложените кластични седименти спрямо по-късна тяхна преработка от страна на флувиална дейност или нови дебритни потоци.

Диамиктони са описани за прьв път от пещери на остров Нова Гвинея (Gillieson, 1986), а покъсно са установени в пещерите Mystic (Западна Виржиния, САЩ), Butler (Виржиния, САЩ), Ponor-Plopa (Южни Карпати, Румъния), Tarimba (Централна Бразилия) и Granito (Централни Пиренеи, Испания).

Бъдещи изследвания могат да бъдат насочени към микропетрографски, минераложки, химичен и изотопен анализ на спелеотемите чрез комплексна методика, като една от главните цели се свежда до получаване на геохроноложки данни и съответно прецизиране на възрастта на кластичния пълнеж.

\section{Литература}

References

Angelova, D., M. A. Belfoul, S. Bouzid, F. Faik. 2005. Karst and cave systems in Bosnek Region (Vitosha Mountain, Bulgaria) and Wintimdouine (High-Atlas Mountain, Morocco). - Acta Carsol., 34, 87-111; https://doi.org/10.3986/ ac.v34i1.281.

Bosch, R. F., W. B. White. 2004. Lithofacies and transport of clastic sediments in karstic aquifers. - In: Sasowsky, I. D., J. E. Mylroie (Eds.). Studies of Cave Sediments. New York, Kluwer Academic/Plenum Publ., 1-22; https://doi. org/10.1007/978-1-4419-9118-8 1.

Gillieson, D. 1986. Cave sedimentation in the New Guinea Highlands. - Earth Surf. Process. Landf., 11, 533-543; https://doi.org/10.1002/esp.3290110508.

Herman, E. K., L. Toran, W. B. White. 2012. Clastic sediment transport and storage in fluviokarst aquifers: an essential component of karst hydrogeology. - Carbon. Evapor., 27, 211-241; https://doi.org/10.1007/s13146-012-0112-7.

Shanov, S., K. Kostov. 2015. Dynamic Tectonics and Karst. Cave and Karst Systems of the World. Berlin-Heidelberg, Springer-Verlag, 123 p.; https://doi.org/10.1007/978-3662-43992-0. 